\title{
Reexamining the Monetarist Critique of Interest Rate Rules
}

\author{
Robert G. King and Mau-Ting Lin
}

\begin{abstract}
Monetarist economists argued long ago that central bank interest rate rules exacerbate macro economic fluctuations, essentially by not allowing the interest rate to respond promptly to shifts in the supply and demand for loans. To support this critique, they pointed to the procyclicality of the money stock. Yet, when there are real shocks and a real business cycle, modern macroeconomic models imply that some procyclicality of money is desirable, to stabilize the price level. A simple interest rate rule illustrates that the monetarist critique can be valid within this model, since the rule exacerbates the response of real activity to real shocks. Other interest rate rules instead limit the macro economy's response to real shocks. But, while these interest rate rules have diverse effects on real activity, there is an important common implication: By smoothing the nominal interest rate in the short run, the rules all lead to increases in the longer-run variability in inflation and nominal interest rates.
\end{abstract}

Federal Reserve Bank of St. Louis Review, July/August 2005, 87(4), pp. 513-30.

\section{INTRODUCTION}

$\mathbf{O}$ nce upon a time, the nature of the short-term nominal interest rate was a central dispute among macroeconomists. Keynesian economists stressed that it was the opportunity cost of holding money. Monetarist economists stressed that the nominal rate was a central part of an intertemporal price, with the real interest rate the equating market for loan supply and demand.

Such divergent perspectives led these groups of macroeconomists to subscribe to different policies for the management of interest rates. Viewing the demand for money as fluctuating substantially over time and viewing the short-term nominal interest rate as principally affected by monetary factors, Keynesian macroeconomists argued for holding the interest rate fixed as economic activity fluctuated or, at least, varying it gradually over time. Viewing loan supply and demand as sub- ject to important real shocks, monetarist economists argued for allowing interest rates to fluctuate more widely, while seeking to control a monetary aggregate for stabilization purposes. More specifically, Brunner (1978), Friedman $(1968,1985)$, and particularly Poole (1978) argued that the Federal Reserve System's unwillingness to change interest rates over time exacerbated the business cycle, leading the central bank to make the money supply procyclical. ${ }^{1}$

In recent years, macroeconomic analysis has increasingly used small, fully articulated quantitative macroeconomic models to study the effects of alternative monetary policies. In the terminology of King and Wolman (1996), these are the "St. Louis models of the 21st Century," capable of exploring alternative policies in a manner

\footnotetext{
1 For example, in an interview in this Review, Brunner (1978) argues "apparently uncontrollable money growth... essentially results from the central bank's unwillingness, or political inability, to adjust the interest rate...to the realities of the market place."
}

Robert G. King is a professor of economics at Boston University, a research associate at the National Bureau of Economic Research, and an editor for the Journal of Monetary Economics. Mau-Ting Lin is an assistant professor of economics at the National University of Singapore.

(C) 2005, The Federal Reserve Bank of St. Louis. Articles may be reprinted, reproduced, published, distributed, displayed, and transmitted in their entirety if copyright notice, author name(s), and full citation are included. Abstracts, synopses, and other derivative works may be made only with prior written permission of the Federal Reserve Bank of St. Louis. 


\section{King and Lin}

consistent with the recommendations of Lucas (1976). ${ }^{2}$ Increasingly, these models are studied with a focus on interest rate rules for monetary policy, particularly variants of the rule put forward by Taylor (1993). In this article, we return to the concerns of Brunner, Friedman, and Poole, studying the effect of some alternative interest rate rules within a modern quantitative macroeconomic model. We are specifically interested in whether monetarist concerns about the exacerbation of the business cycle carry through to modern model economies under alternative interest rate rules related to Taylor's specification. Therefore, in our analysis, we consider three interest rate rules and we explore how each affects the dynamic response of the macroeconomy to two real shocks: shifts in government purchases and productivity. First, we consider an "inflation only" variant of the Taylor rule, in which there is no output gap response. Second, we consider the original Taylor specification. Third, we consider a more dynamically complicated interest rate rule estimated by Orphanides and Wieland (1998), which includes a lagged nominal interest rate term.

To consider how these rules alter the behavior of economic activity, we exploit the fact that there is a "neutral" solution for real activity-the solution that would obtain under flexible prices-that can be brought about by the monetary authority if it fully stabilizes the price level. The neutral real activity solution can be brought about by an interest rate rule that "tracks the natural rate of interest." We use the neutral outcomes as a benchmark for subsequent analysis. The analysis of neutral outcomes also highlights the fact that the procyclicality of money does not, on its own, rationalize the concerns of Brunner, Friedman, and Poole. Since the neutral output solution requires that the price level be stabilized, while real activity fluctuates, money must move positively with real activity. In this regard, our model accords with Friedman's (1969, p. 46) observation that a stable price level requires a specific trend growth rate of money when there is growth in productivity and labor, but we apply this reason-

\footnotetext{
2 Kimball (1995) calls similar models "neomonetarist." Goodfriend and King (1997) describe them as the result of a "new neoclassical syntheses."
}

ing to output responses over the course of a real business cycle.

Using the "inflation only" interest rate rule, we find that this policy exacerbates economic fluctuations for the reasons suggested by Brunner, Friedman, and Poole. Since nominal and real rates should rise immediately in response to both disturbances in the neutral solution, but cannot according to the policy rule, there must be an additional stimulative increase in money. Thus, there is a temporary increase in output relative to the neutral paths relevant for each disturbance. The key to these exacerbation results is that the "inflation only" interest rate rule does not accommodate shifts in the neutral real interest rate.

The other interest rate rules that we consider, the specifications of Taylor (1993) and Orphanides and Wieland (1998), also do not accommodate shifts in the neutral real rate, as shocks to government purchases or productivity take place. However, because there are responses to an output gap measure in these rules, their implications are more complicated. We find that these rules restrictrather than exacerbate-cyclical variations in output that arise from real shocks. In effect, when there is a rise in real economic activity from our demand shock (government purchases) or supply shock (productivity), these rules call for a smaller degree of monetary accommodation than would occur under neutral policy. Hence, increases in government purchases and productivity both bring about declines in the price level for several quarters, which are associated with temporary declines in output relative to the neutral level. Strikingly, given the empirical analysis of Galí (1999), both our Taylor and Orphanides-Wieland specifications imply that there is a small absolute decline in output when there is a positive productivity shock, which translates into an important decline in labor input. ${ }^{3}$

While the interest rate rules that we study have

\footnotetext{
3 Working within a modern macroeconomic model, but with staggered price setting at a 4-quarter horizon, Dotsey (2002) finds that the Taylor rule does not involve a decline in labor input. Although there are a number of other differences between the models, one is tempted to conclude that the discrepancy between his results and ours suggests that the effect of interest rate rules depends importantly on the details of the price-setting structure.
} 
diverse consequences for real activity, there is an important common implication: By smoothing the nominal interest rate in the short-run, the rules all lead to a substantial increase in the variability of nominal interest rates. That is, the interest rate rules all lead to low-frequency variation in inflation, which is essentially neutral and thus fully reflected in the nominal rate. Such increased volatility in inflation and nominal interest rates is another standard monetarist concern about interest rate rules (Friedman, 1968, and Poole, 1978).

The organization of the paper is as follows. Section 2 describes the macroeconomic model that we employ in this paper. Section 3 discusses the response of the macroeconomy to real government purchase and real productivity shocks, under the assumption of "neutral policy," which stabilizes the path of the price level and produces outcomes that are equivalent to a real business cycle model. Section 4 considers how the dynamic responses differ under our three interest rate rules. Section 5 is a summary and conclusion.

\section{A ST. LOUIS MODEL}

The small quantitative macroeconomic model that we use is closely related to those in King and Watson (1996), King and Wolman (1996), and Yun (1996). ${ }^{4}$

\subsection{Households}

There are many identical households in the economy. Each values a composite consumption good, $c$, and leisure, $l$, as summarized by the expected utility objective

$$
E_{t} \sum_{j=0}^{\infty} \beta^{j} u\left(c_{t+j}, l_{t+j}\right) .
$$

The household can invest in various financial instruments, including government bonds at price $1 /\left(1+R_{t}\right)$, and in a diversified portfolio of claims to firms at price $\underline{v}_{t}$. It also makes invest-

\footnotetext{
4 The calibration and computation follow directly from King and Wolman (1996), with all parameters matching that study with one exception, which is that we assume a smaller extent of investment adjustment costs. The economy is linearized around a zero inflation steady state and solved as a linear rational expectations model. Replication materials for the analysis are available at http://people.bu/edu/rking/Research.htm.
}

ments, $i_{t}$, in real capital, which it rents to firms in the economy at rental rate, $q_{t}$. Its receives wage rate $w_{t}$ for units of work $n_{t}$ and receives lump-sum transfers or taxes from the government in amount $T_{t}$. Thus, its one-period budget constraint takes the form

$$
\begin{aligned}
& c_{t}+i_{t}+\frac{1}{1+R_{t}} b_{t+1}+\underline{v}_{t} e_{t+1} \\
& =\left[b_{t} \frac{P_{t-1}}{P_{t}}+\left(\underline{v}_{t}+\underline{z}_{t}\right) e_{t}+w_{t} n_{t}+q_{t} k_{t}+T_{t}\right] .
\end{aligned}
$$

In this expression, $b_{t}$ and $e_{t}$ are the quantities of bonds and equities held at the start of period $t$. The household faces three other constraints. First, capital evolves according to

$$
k_{t+1}-k_{t}=h\left(\frac{i_{t}}{k_{t}}\right) k_{t}-\delta k_{t} .
$$

In this expression, the rate of depreciation is $\delta$ and $\phi$ is an increasing, concave function $(h(0)=0)$, which allows for capital stock adjustment costs as in Hayashi (1982). Second, the household has a time constraint,

$$
n_{t}+l_{t} \leq 1
$$

Third, the household must hold an asset-fiat money-in sufficient quantity to pay for its consumption and investment expenditures, as well as tax payments to the government that are necessary to finance its real expenditures:

$$
m_{t}=\frac{M_{t}}{P_{t}}=\left(c_{t}+i_{t}+g_{t}\right) .
$$

We do not model the demand for money explicitly, simply assuming that the quantity equation holds. ${ }^{5}$ In this regard, we depart from King and Wolman (1996), who introduced a shopping time technology to motivate money demand holding and derived detailed information on "transactions wedges” in an otherwise similar model. In the current analysis, we follow the strategy more

\footnotetext{
5 One way to think about this assumption is that it involves interest payments on the monetary aggregate, which is relevant for transactions purposes, but with a small spread so that the demand for money is determinate. Under this interpretation, it is appropriate to ignore revenue from money creation in the household budget constraint.
} 


\section{King and Lin}

widely used in analysis of sticky price models, to stress that our results on policies are not dependent on a particular transactions technology and the implied money demand structure.

Given the problem just noted, we can cast the decision problem of households in dynamic programming form and derive efficiency conditions that restrict its optimal choices. First, individuals choose consumption and work efficiently:

$$
\begin{aligned}
& u_{c}\left(c_{t}, l_{t}\right)-\lambda_{t}=0 \\
& u_{l}\left(c_{t} l_{t}\right)-\lambda_{t} w_{t}=0 .
\end{aligned}
$$

In these expressions, $\lambda_{t}$ is a Lagrange multiplier on (2) and $w_{t}$ is a real wage rate. Second, individuals choose holdings of nominal and real bonds according to Fisherian principles,

$$
\begin{gathered}
1=\beta E_{t}\left[\left(1+R_{t}\right) \frac{\lambda_{t+1}}{\lambda_{t}} \frac{P_{t}}{P_{t+1}}\right] \\
1=\beta E_{t}\left[\left(1+r_{t}\right) \frac{\lambda_{t+1}}{\lambda_{t}}\right],
\end{gathered}
$$

where $r_{t}$ is a shadow real interest rate-which is determined so that the supply and demand for real bonds is zero-and $R_{t}$ is the market-determined nominal interest rate.

\subsection{Microgoods}

Consumption, investment, and government aggregates are produced, using a standard DixitStiglitz (1977) specification, from a continuum of goods on the unit interval. For example, the consumption aggregate is

$$
C_{t}=\left[\int_{0}^{1}\left[C_{t}(i)^{\frac{(\varepsilon-1)}{\varepsilon}} d i\right] \frac{\varepsilon}{\varepsilon-1} .\right.
$$

Cost minimization implies that the demand for the ith good takes the form

$$
C_{t}(i)=\left(\frac{P_{t}(i)}{P_{t}}\right)^{-\varepsilon} C_{t},
$$

where $P_{t}(i)$ is its nominal price and $P_{t}$ is the price level, which Yun (1996) demonstrates takes the form

$$
P_{t}=\left[\int_{0}^{1} P_{t}(i)^{1-\varepsilon} d i\right]^{\frac{1}{1-\varepsilon}}
$$

We assume that the same aggregator governs investment and government purchases, so that the demand for the ith product then takes the form

$$
\left(\frac{P_{t}(i)}{P_{t}}\right)^{-\varepsilon}\left(C_{t}+i_{t}+g_{t}\right),
$$

where $c_{t}+i_{t}+g_{t}=d_{t}$ is aggregate demand.

\subsection{Firms}

As in many macroeconomic analyses with the "New Keynesian" elements surveyed in Rotemberg (1987), we assume that firms are monopolistic competitors facing exogenous opportunities for price adjustment in the Calvo (1983) manner. Each firm rents labor and capital from households, combining these factors to produce its output according to a constant returns-to-scale production function of the Cobb-Douglas form. Looking at firm $i$, its output is

$$
y_{t}(i)=a_{t}\left(k_{t}(i)\right)^{1-\alpha}\left(n_{t}(i)\right)^{\alpha},
$$

where $a_{t}$ is an aggregate productivity shifter, which is constant across firms. Given this specification, the firm's real marginal cost of producing output, $\psi_{t}$, is independent of its output level and equal to

$$
\psi_{t}=\frac{w_{t}^{\alpha} q_{t}^{1-\alpha}}{a_{t}\left[(1-\alpha)^{1-\alpha} \alpha^{\alpha}\right]} .
$$

The absence of the firm index, $i$, reflects the fact that all firms have the same marginal cost, which varies with wage and rental rates. Firms set nominal prices, acting as monopolistic competitors and recognizing that they may be unable to adjust prices in future periods (with probability $\eta$ ). They have a forward-looking pricing rule of the form

$$
\frac{P_{0 t}}{P_{t}}=\frac{\varepsilon}{\varepsilon-1} \frac{\sum_{j=0}^{\infty}(\beta \eta)^{j} E_{t}\left\{\left(\lambda_{t+j} / \lambda_{t}\right) \cdot \psi_{t+j} \cdot d_{t+j}\right\}}{\sum_{j=0}^{\infty}(\beta \eta)^{j} E_{t}\left\{\left(\lambda_{t+j} / \lambda_{t}\right) \cdot\left(P_{t+j} / P_{t}\right) \cdot d_{t+j}\right\}} \text {. }
$$

That is, the firm sets price as a markup over discounted measures of costs and demand, as discussed previously by King and Wolman (1996), Yun (1996), and others. 


\subsection{Aggregation}

Since there is a continuum of firms on the unit interval (so that the law of large numbers applies) and since the probability of being unable to adjust in a given period is $\eta$, the stationary distribution of firms by age of price is $\omega_{j}=(1-\eta) \eta^{j}$ for $j=0,1,2 \ldots$ Accordingly, as stressed by Yun, there is an aggregate production function that depends on linear aggregates of inputs used by firms with various vintages of prices, $y_{t}=a_{t} f\left(k_{t}, n_{t}\right)$,

with $k_{t}=\sum_{j=0}^{\infty} \omega_{j} k_{j t}$ and $n_{t}=\sum_{j=0}^{\infty} \omega_{j} n_{j t}$

that can be used for purposes such as extraction of a Solow residual. At the same time, the price level pertinent for the demand analysis previously noted takes a nonlinear form:

$$
P_{t}=\left[\sum_{j=0}^{\infty} \omega_{j}\left(P_{j t}\right)^{1-\varepsilon}\right]^{\frac{1}{1-\varepsilon}}=\left[(1-\eta) P_{0 t}^{1-\varepsilon}+\eta P_{t}^{1-\varepsilon}\right]^{\frac{1}{1-\varepsilon}}
$$

National income identities require that

$$
\left(c_{t}+i_{t}+g_{t}\right) \delta_{t}=y_{t},
$$

with

$$
\delta_{t}=\sum_{j=0}^{\infty} \omega_{j}\left(\frac{P_{j t}}{P_{t}}\right)^{-\varepsilon}
$$

being a measure of relative price distortions. Because we will assume that the economy is operating at a low (zero) inflation rate, variations in $\delta_{t}$ are locally unimportant.

\subsection{Neutral Policy Rule}

We close this model with an interest rate policy rule. Our benchmark is a "neutral" policy rule that involves strict inflation management. This interest rate rule takes the form

$$
R_{t}=r_{t}^{*}+f\left[\log \left(P_{t}\right)-\log (\bar{P})\right] .
$$

In this expression, $r_{t}^{*}$ is the level of the real interest rate-sometimes called the "natural rate" of interest-that would arise if output were continuously at its flexible price level. With a large value of $f$, this rule may alternatively be approximated by

$$
\begin{aligned}
R_{t} & =r_{t}^{*} \\
\log \left(P_{t}\right) & =\log \left(P_{t-1}\right)=\log (\bar{P}) .
\end{aligned}
$$

Under this policy rule, then, actual and expected inflation are always zero. As stressed by King and Wolman (1996) and Goodfriend and King (1997), the economy operates at its "natural rate" level, i.e., delivers the same time series of output and other real variables as would arise if prices were completely flexible.

\subsection{Taylor Rules}

The next two rules are based on the work of John Taylor (1993), with greater than one-for-one increases in the nominal interest rate when inflation exceeds a specified benchmark level (treated here as zero for expositional ease). We write Taylor rules as

$$
R_{t}=r^{*}+\tau_{1}\left(\frac{1}{T_{1}} \sum_{j=1}^{T_{1}} \pi_{t-j}\right)+\tau_{2}\left(\log \left(y_{t-1}\right)-\log \left(\bar{y}_{t-1}\right)\right) .
$$

That is, the nominal interest rate is adjusted in response to an average of recent inflation and in response to a measure of the output gap. Rather than specifying an economic model of the output gap, we let it be deviation of output from an average of past values,

$$
\log \left(y_{t-1}\right)-\log \left(\bar{y}_{t-1}\right)=\left[\log \left(y_{t-1}\right)-\frac{1}{T_{2}} \sum_{j=1}^{T_{2}} \log \left(y_{t-j}\right)\right] .
$$

We do not require that the lags in these expressions be the same; indeed, our Taylor rule cases involve responses to annual average inflation $\left(T_{1}=4\right)$ and deviations of output from a 6-year moving average $\left(T_{2}=24\right)$. We use this simple specification because we think it is a simple description of how standard capacity output measures behave over time.

It is important to stress that our formulation of this rule, like Taylor's original specification, does not involve the central bank "tracking the natural rate of interest." (That is, it is $r^{*}$ not $r_{t}^{*}$ that enters into the policy rule.) In this regard, it is potentially quite different from the neutral policy rule stated previously.

2.6.1 An "Inflation Only" Variant of the Taylor Rule. As a reference point, we begin with 


\section{King and Lin}

an interest rate rule in which the central bank reacts only to inflation and responds only to annual average inflation over the preceding year:

$$
R_{t}=r^{*}+1.5 \cdot\left(\frac{1}{4} \sum_{j=1}^{4} \pi_{t-j}\right) .
$$

In this setting, we use Taylor's 1.5 value for the coefficient $\tau_{1}$. This coefficient value implies that there is a unique stationary rational expectations equilibrium.

2.6.2 A Standard Taylor Rule. Our version of the standard Taylor rule is

$$
R_{t}=r^{*}+1.5\left(\frac{1}{4} \sum_{j=1}^{4} \pi_{t-j}\right)+0.5 \cdot\left[\log \left(y_{t-1}\right)-\log \left(\bar{y}_{t-1}\right)\right] .
$$

That is, in this case, we use both of Taylor's values, setting $\tau_{1}=1.5$ and $\tau_{2}=0.5$. The output gap measure is based on deviations from the 6-year (24-quarter) moving average, i.e.,

$$
\log \left(\bar{y}_{t-1}\right)=\frac{1}{24} \sum_{j=1}^{24} \log \left(y_{t-j}\right) .
$$

These values also imply that there is a unique stationary rational expectations equilibrium.

\subsection{An Estimated Rule}

There has been much recent work on estimating interest rate rules for monetary policy. We employ a particular specification due to Orphanides and Wieland (1998), which takes the form

$$
\begin{aligned}
R_{t} & =r^{*}+0.795\left(R_{t-1}-r^{*}\right)+0.625 \cdot\left(\frac{1}{4} \sum_{j=1}^{4} \pi_{t-j}\right) \\
& +1.17 \cdot\left[\log \left(y_{t}\right)-\log \left(\bar{y}_{t}\right)\right] \\
& -0.97 \cdot\left[\log \left(y_{t-1}\right)-\log \left(\bar{y}_{t-1}\right)\right],
\end{aligned}
$$

where we again take the output gap as a deviation from a 6-year moving average. In our model, these values also imply that there is a unique stationary rational expectations equilibrium.

\section{NEUTRAL BENCHMARKS}

Our starting point is the responses that obtain in the "core real business cycle model" within our sticky price model. There are two interpretations of these responses, which we use interchangeably, with one important exception discussed in detail hereafter.

The first interpretation is that prices are completely flexible, so that we are essentially looking at the workings of a real business cycle (RBC) model. This set of outcomes is not efficient, because there is monopoly power, but represents one definition of the natural rate of output (see Goodfriend and King, 1997, and Woodford, 2003).

The second interpretation is that monetary policy is conducted, as in section 2.5.1, to fully smooth the price level. Under this policy, real outcomes are those of the RBC solution, but nominal money must also be determined so that real balances satisfy the quantity equation at the specified price level. That is, activist monetary policy is required to smooth the price level in the presence of real shocks.

Hence, the two interpretations differ only on the path of money: It is not incorporated in the RBC solution (and could be anything), and it takes on particular values in the pegged price level case. Accordingly, our figures report the path of the money stock under the latter interpretation.

\subsection{Response to Government Purchases}

We consider a unit increase in government purchases under the assumption that the stationary share of government purchases is 20 percent $(g / y=0.2)$. We assume that this increase is persistent, but ultimately temporary, with government purchases being governed by $g_{t}=\rho g_{t-1}+e_{g t}$ with $\rho=0.9$. The increase in government purchases is usefully thought of in two ways. First, it is a "demand shift," increasing the level of aggregate demand at a given real interest rate. Second, it is a "resource shift," amounting to a decrease in the output available for consumption and investment, without altering the level of the production function or its marginal products. ${ }^{6}$

The dynamic response to this shock is shown in Figure 1. The shock is a 5 percent movement in government purchases, which translates into 6 That is, in the terminology of Baxter and King (1993), we are con-
sidering the case of basic government purchases. 


\section{Figure 1}

\section{Effects of a Rise in Government Purchases Equal to 1 Percent of GDP Under Strict Price Level Constancy}
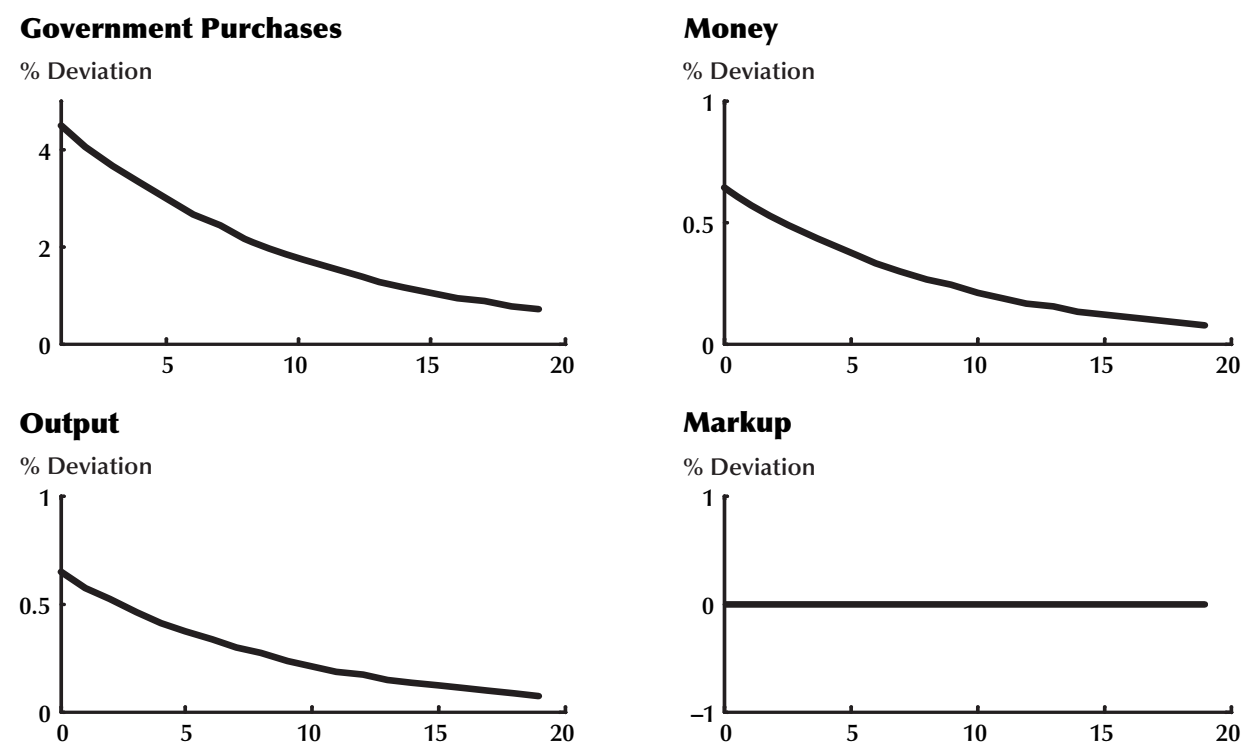

\section{Nominal Interest Rate}

\section{Real Interest Rate}
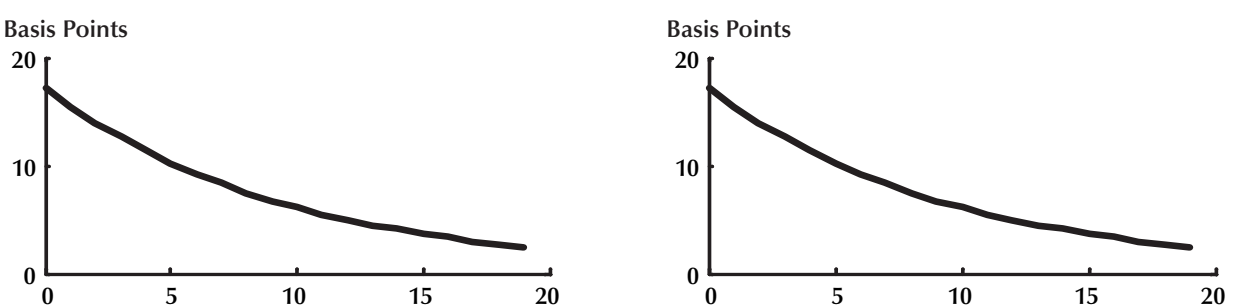

a 1 percent variation in resources available to the private sector because $g / y=0.2$ in the stationary state. The government purchase shock requires about a 0.5 percent increase in the money stock, because the neutral private response is to increase output by about 0.5 percent. The price level response is, of course, zero under this policy.

In terms of dynamic responses of model variables, we focus on four variables that will play a role in subsequent discussion. First, output increases because individuals choose to respond in part by working harder and in part by decreasing consumption. Second, the markup charged by firms does not change, simply staying at $\mu=\varepsilon /(\varepsilon-1)$. Third, the real interest rate rises to stimulate work and to discourage consumption and investment. Fourth, given the absence of expected inflation, the response of the nominal rate is identical to the response of the real rate. The rate increase is quite small, about 20 basis points, despite the presence of substantial investment adjustment costs. This small response reflects the willingness of individuals to substitute consumption and work across time in response to changed intertemporal incentives.

\subsection{Response to Productivity}

We consider the effects of a permanent 1 percent increase in total factor productivity, as displayed in Figure 2. As we have structured it, this permanent productivity shock has the implication 
Figure 2

Effects of a 1 Percent Rise in Total Factor Productivity Under Strict Price Level Targeting
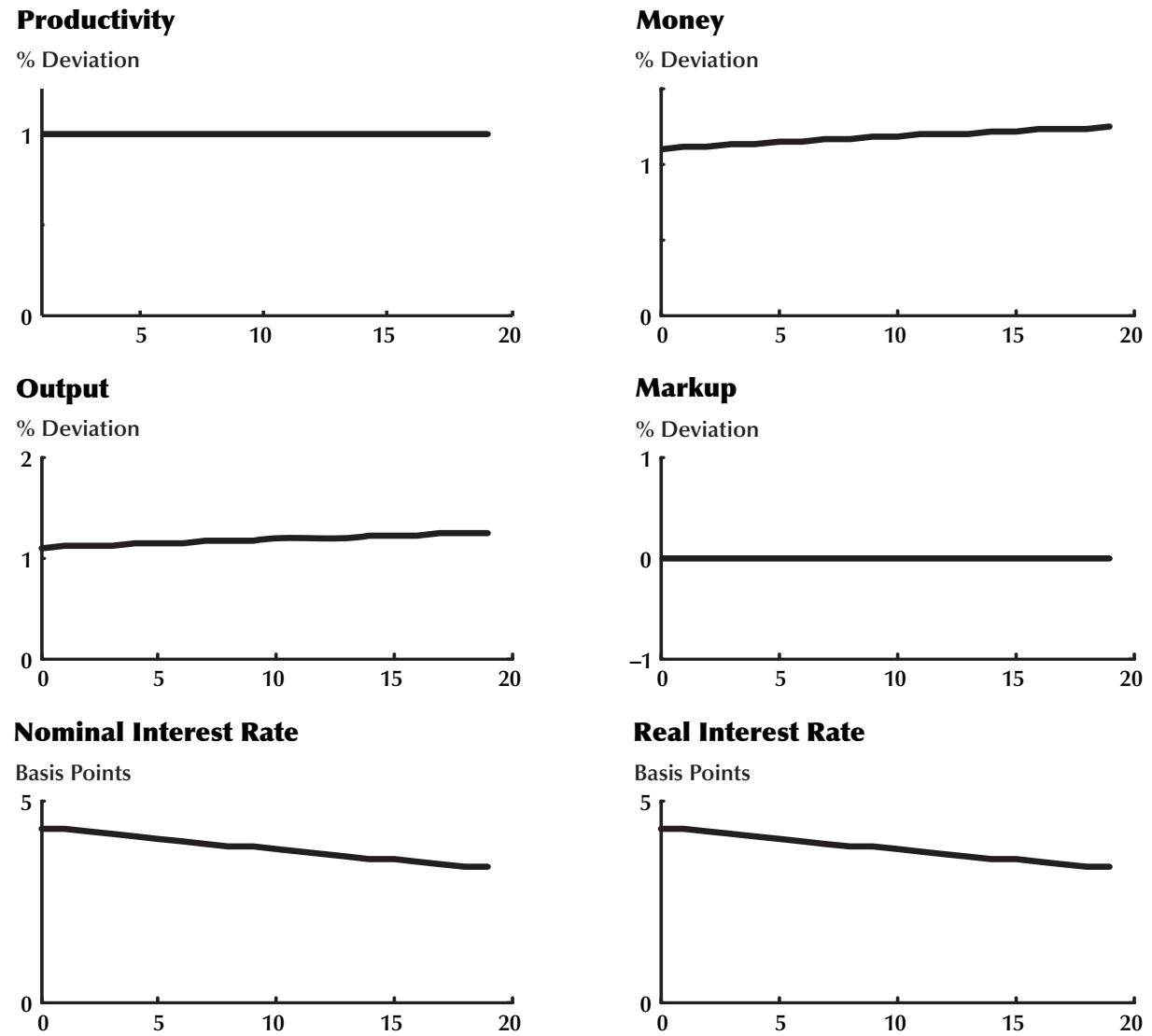

Real Interest Rate

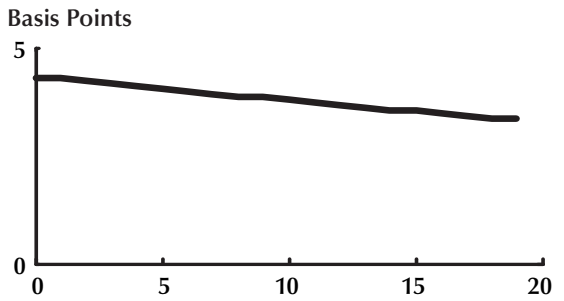

that there is no long-run labor response and there is thus a $1 / \alpha=1.72$ percent effect on the level of output. $^{7}$

The dynamic responses involve a jump in output, followed by a gradual increase toward the new higher steady-state level. The presence of quantitatively important investment adjustment costs means that the equilibrium response of labor to productivity shocks is fairly small. Under flexible prices/strict price level constancy, the average markup does not change in response to this shock, as it also earlier remained constant in the face of

7 This zero long-run labor response requires that the permanent productivity shock leaves the $g / y$ ratio unchanged in the long run.

To accomplish this, we assume that the government continuously maintains a constant $g / y$ ratio in the face of this shock. government purchase shocks. Variations in the real interest rate in response to this productivity shock are quite small, even in the presence of investment adjustment costs: A large increase in productivity produces only a relatively minor increase in the real interest rate.

\section{RESPONSE UNDER INTEREST RATE RULES}

We now consider the dynamic implications of the three standard interest rate rules, studying the response of the macroeconomy to government purchase and productivity shocks in each case. All results are compared with the benchmark results from Figures 1 and 2, which are the results 


\section{Figure 3}

\section{Effects of a Rise in Government Purchases Equal to 1 Percent of GDP Under an Interest Rate Rule that Responds Only to Inflation}
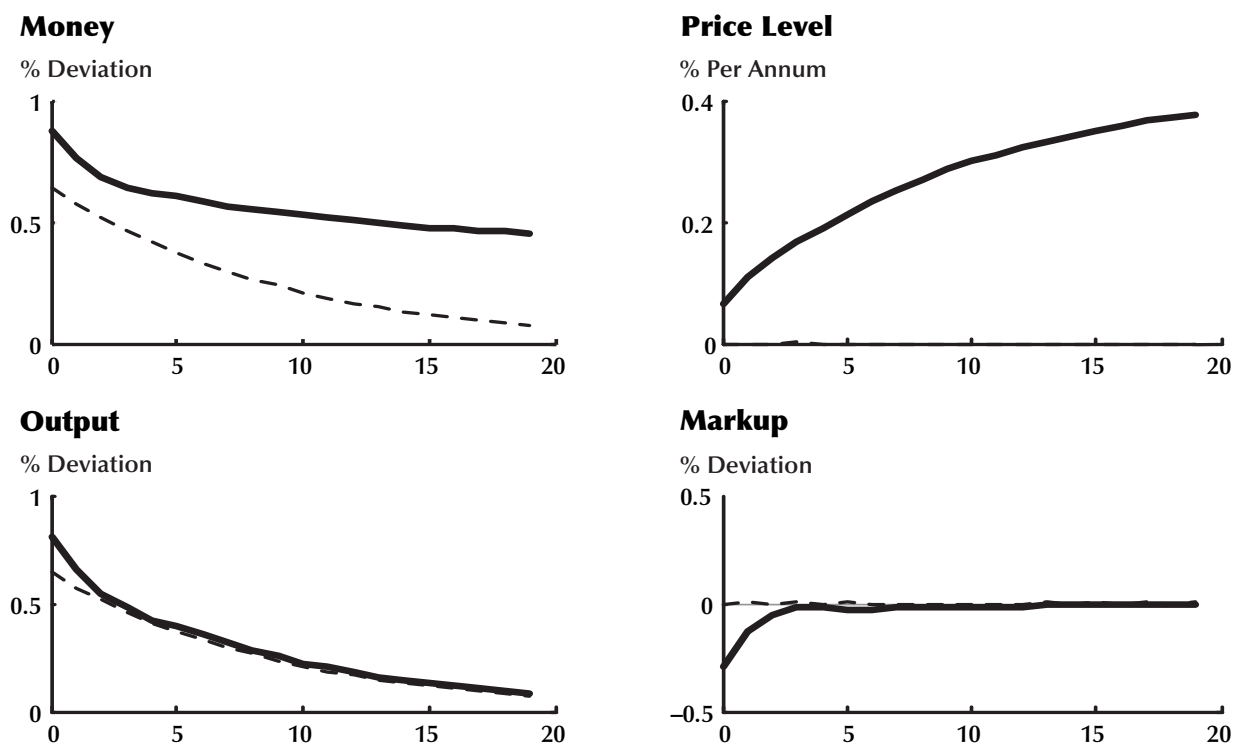

\section{Markup}

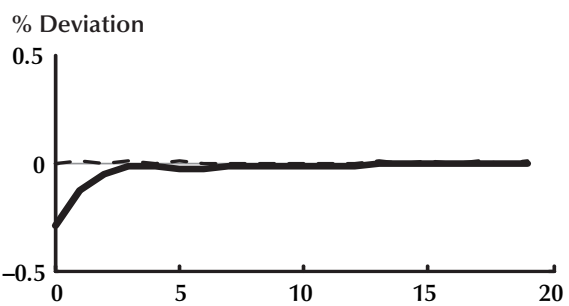

\section{Nominal Interest Rate}

Real Interest Rate
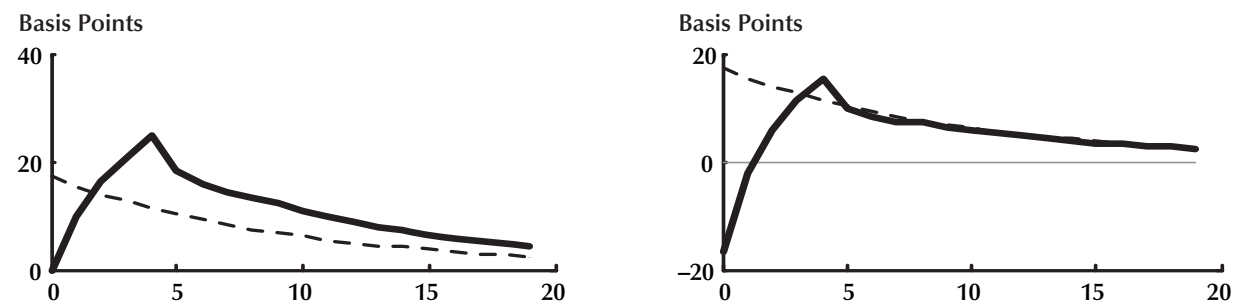

that would obtain under strict price level targeting or, equivalently, under flexible prices.

\subsection{An Example}

As background to analysis of all of the rules, it is useful to consider the following simple equation system. Suppose that the nominal interest rate is given by a Fisher equation,

$$
R_{t}=r_{t}+E_{t} \pi_{t+1}
$$

as will indeed be the case in our model. Suppose further that the monetary policy rule takes the simple form

$$
\begin{aligned}
& R_{t}=r^{*}+\tau \bar{\pi}_{t-1} \\
& \bar{\pi}_{t}=\xi \pi_{t}+(1-\xi) \bar{\pi}_{t-1} .
\end{aligned}
$$

This policy rule involves no response to deviations of the real rate from its long-run value and no real output term. However, the nominal rate does respond to an exponentially weighted average of inflation.

These equations can be solved to yield $E_{t} \bar{\pi}_{t+1}-(1-\xi) \bar{\pi}_{t}-\tau \xi \bar{\pi}_{t-1}=-\xi\left(r_{t}-r^{*}\right)$. With $\tau>1$, $0<\xi<1$ and $\tau<((2-\xi) / \xi)$, there is a unique stable rational expectations solution,

$$
\bar{\pi}_{t}=\sum_{j=0}^{\infty}\left(\frac{1}{\theta_{1}}\right)^{j+1} \xi\left[E_{t} r_{t+j}-r^{*}\right]+\theta_{2} \bar{\pi}_{t-1},
$$

where $\theta_{1}>1$ and $-1<\theta_{2}<0$. Hence, the "average" inflation rate that enters in the policy rule is positively related to a present value of interest rates and negatively to its own past values. 


\section{Figure 4}

\section{Effects of a 1 Percent Rise in Total Factor Productivity Under an Interest Rate Rule that Responds Only to Inflation}
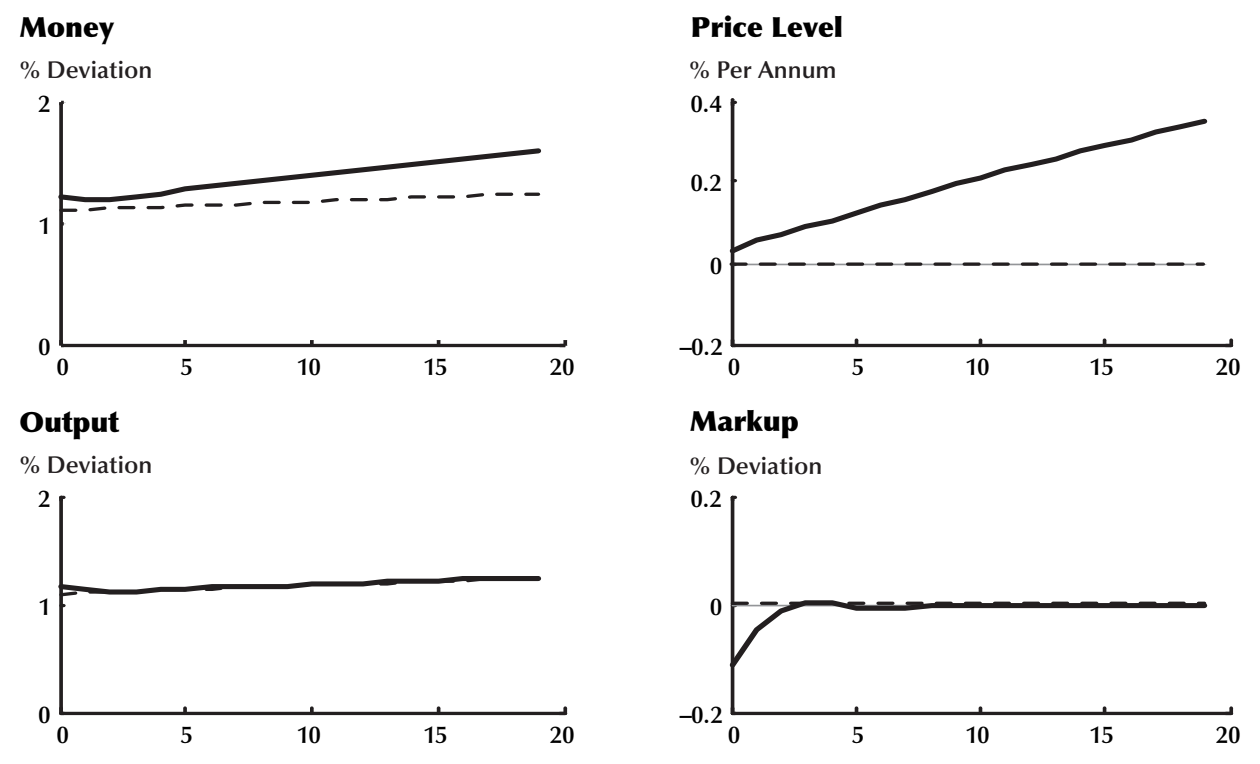

Nominal Interest Rate

\section{Real Interest Rate}
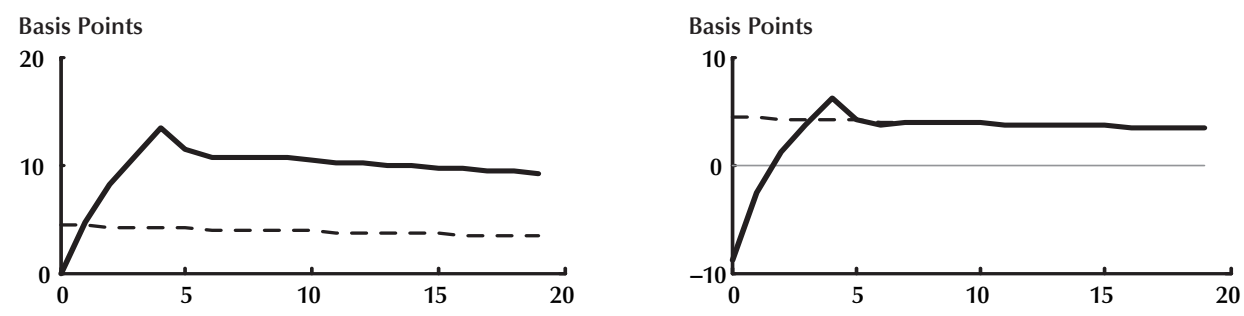

Next, assume that the real interest rate is exogenous and is governed by a first-order stochastic difference equation, $\left[r_{t}-r^{*}\right]=\rho\left[r_{t}-r^{*}\right]+e_{t}$. Then, it follows that average inflation obeys

$$
\bar{\pi}_{t}=\frac{\xi}{\theta_{1}-\rho}\left[r_{t}-r^{*}\right]+\theta_{2} \bar{\pi}_{t-1}
$$

and thus that the nominal interest rate evolves according to

$$
R_{t+1}=\frac{\tau \xi}{\theta_{1}-\rho}\left[r_{t}-r^{*}\right]+\theta_{2} R_{t} .
$$

Hence, the nominal interest rate inherits the persistence of the real interest rate, but this is somewhat mitigated due to the presence of the lagged interest rate term that derives from the central bank's concern about average inflation. The solution to this difference equation implies that

$$
\begin{array}{r}
E_{t} R_{t+k+1}-E_{t} R_{t+k}=\left[\frac{\tau \xi}{\theta_{1}-\rho}\right]\left[\frac{\rho^{k+1}-\theta_{2}^{k+1}}{\rho-\theta_{2}}\right] e_{t} \\
=\frac{\tau \xi}{\tau \xi-\rho[\rho-(1-\xi)]}\left[\rho^{k+1}-\theta_{2}^{k+1}\right] e_{t} .
\end{array}
$$

Accordingly, shocks to the real interest rate exert an amplified influence on the future nominal interest rate under two conditions. First, it must be the case that $\rho>(1-\xi)$, which is the restriction that the real rate process involves more persistence than the inflation averaging process. Second, it must be the case that one is looking 
Figure 5

\section{Effects of a Rise in Government Purchases Equal to 1 Percent of GDP Under the Standard Taylor Rule}

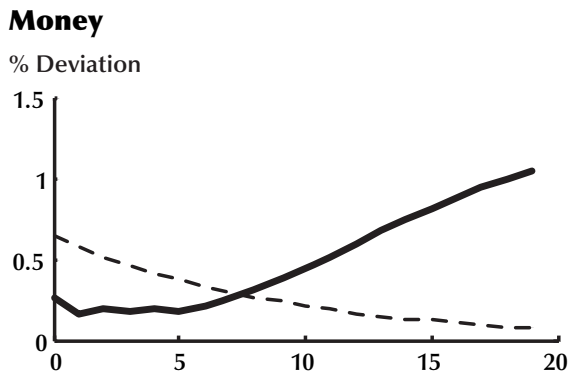

\section{Price Level}

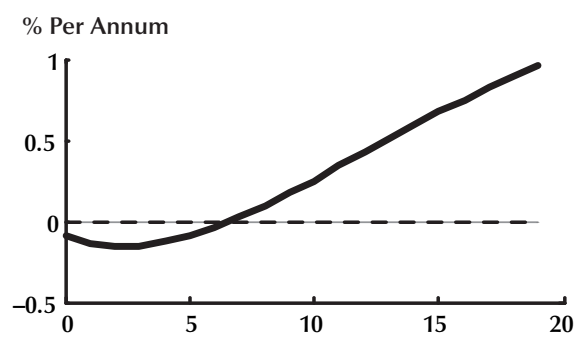

Output

$\%$ Deviation

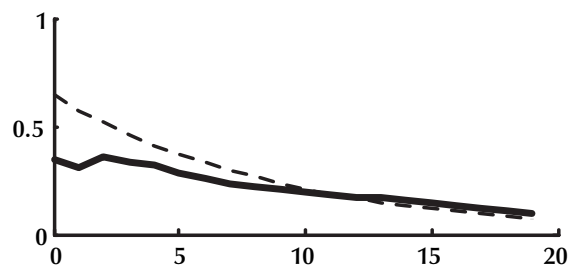

Markup

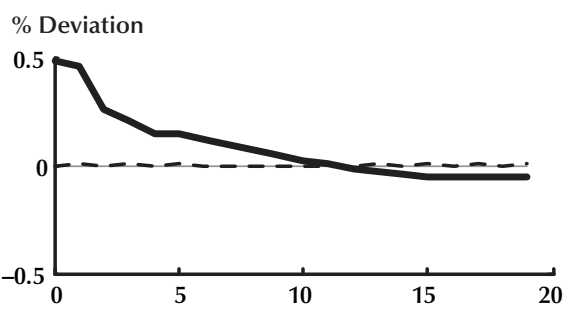

Nominal Interest Rate

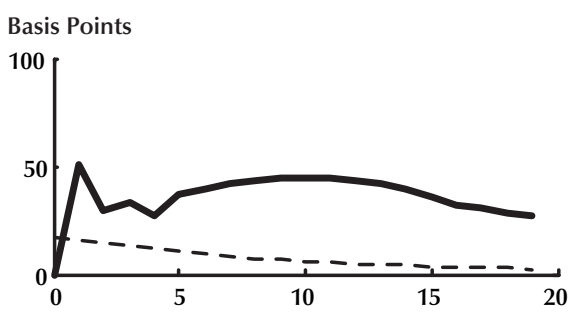

Real Interest Rate

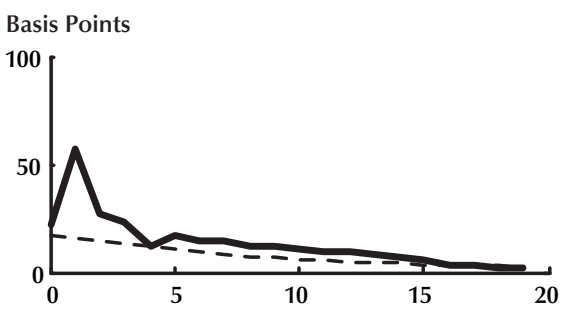

sufficiently far ahead that the effects of $\theta_{2}$ are negligible. Under these two conditions, the real rate then affects the nominal rate with a greater than one-for-one effect because

$$
\frac{\tau \xi}{\tau \xi-\rho[\rho-(1-\xi)]}>1 .^{8}
$$

This example highlights the fact that interest rate policies can ultimately produce a positive

${ }^{8}$ As an example, suppose that $\tau=1.5$ as in Taylor's analysis and that $\xi$ is set equal to 0.4 as a rough approximation to 4 -quarter averaging (the same mean lag). Finally, suppose that the real rate is quite persistent, with $\rho=0.9$ These parameters imply that $\theta_{2}=-0.54$. After 6 quarters (since $0.54^{6}=0.02$, the economy would be left a nominal rate that was about $\tau \xi /[\tau \xi-\rho(\rho-(1-\xi))]=1.82$ times as high as the real rate. comovement of the real interest rate and expected inflation. That is, one legacy of stabilizing the nominal interest rate in the short run against shifts in the real interest rate is to produce longer-run variations in inflation. Of course, the Fisher equation and the interest rate rules are only part of modern macroeconomic models and it is not the case that the real interest rate is exogenous. However, the mechanisms of this simple model provide insight into aspects of the general equilibrium dynamics discussed hereafter.

\subsection{The "Inflation Only" Rule}

We start by considering the implications of an interest rate rule (17), which depends only on recent inflation. 


\section{Figure 6}

\section{Decomposition of Nominal Interest Rate Variations in Response to a Government Purchase Shock Under the Taylor Rule}

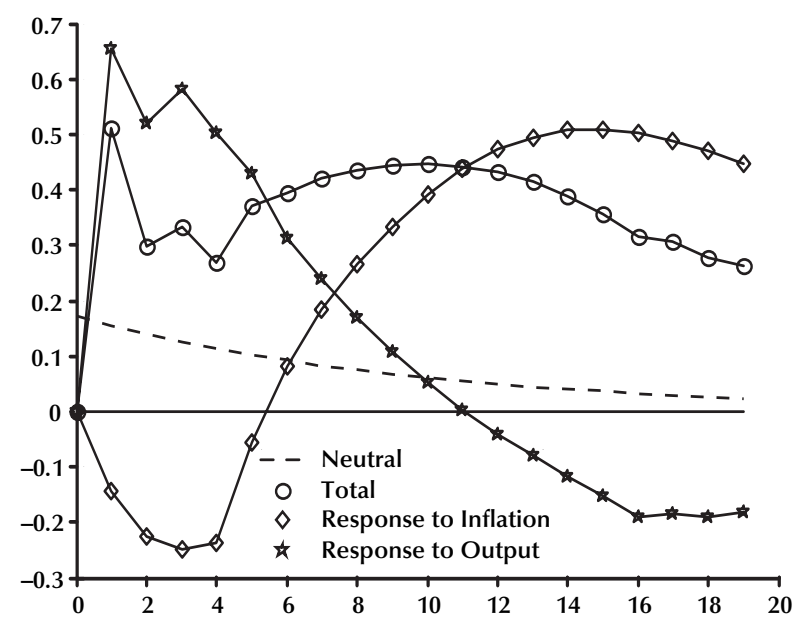

4.2.1 Government Purchases. Figure 3 shows the effects of a rise in government purchases. In line with the suggestions of Brunner, Friedman, and Poole, the dynamic responses in this case involve an exacerbation of the benchmark responses for real output (the neutral responses are the dashed lines in this and subsequent figures). Given that the nominal interest rate is predetermined and the neutral responses (introduced in Figure 1 and repeated as the dashed lines in Figure 3) involve a rise in the real interest rate, there is a tension: There must be either a departure of the real interest rate from its neutral level or a decline in expected inflation. This tension is resolved by a transitory increase in output beyond the benchmark level, which gives individuals an incentive to save and reduces the upward pressure on the real interest rate. As part of the process, the money stock expands more rapidly than in the neutral case, as suggested by Brunner, Friedman, and Poole.

To fit the dynamics together, here and below, we have found it useful to adopt the monetarist perspective, taking the path of the money stock as exogenous and using this path to explain the variations that arise in other variables, including the nominal interest rate (which is governed by the policy rule). To start on this approach, note that Figure 3 implies that the path for money exceeds the neutral policy path. Further, money rises more in the short run than it does in the long run. Given this increase in money, either real income $(y)$ or the price level $(P)$ must increase (or both). With output temporarily high relative to the neutral path, the real interest rate will be lower than the neutral path. But, given that there is expected inflation and the nominal interest rate is predetermined, the real interest rate must actually fall on impact.

After a few quarters or so, real activity is largely on the neutral path. Hence, after this point in the impulse responses, the simple model introduced here previously can be used: The central bank's focus on inflation leads to higher nominal interest rates, which rise more than one-for-one with the real interest rate.

4.2.2 Productivity. Figure 4 shows the dynamic effects of a rise in total factor productivity if the central bank adjusts the interest rate solely in response to recent inflation experience, in line with (17). In this case, the money stock increases relative to the neutral level and then continues to grow for many periods. Similar to the government purchase response, there is a temporary stimulation, although it is smaller and of less-protracted duration. As a consequence, there is a temporary decline in the real interest rate relative to the neutral solution. As was the case with government purchases, output is on the neutral path after about four quarters, so that the simple model can be used to explain the comovement of nominal and real interest rates.

4.2.3 Relationship to Monetarist Critique(s). The two examples studied here show that there can be an "exacerbation" of short-run output responses under an interest rate rule. ${ }^{9}$ However, the exacerbation of real responses is small relative to the overall effect of the disturbances on economic activity.

After the initial interval of monetary non-

\footnotetext{
${ }^{9}$ Quantitatively, the effects are not too large in the current setting, which incorporates no recent mechanisms to increase the amplitude and persistence of monetary shocks.
} 


\section{Figure 7}

\section{Effects of a 1 Percent Rise in Total Factor Productivity Under the Standard Taylor Interest Rate Rule}
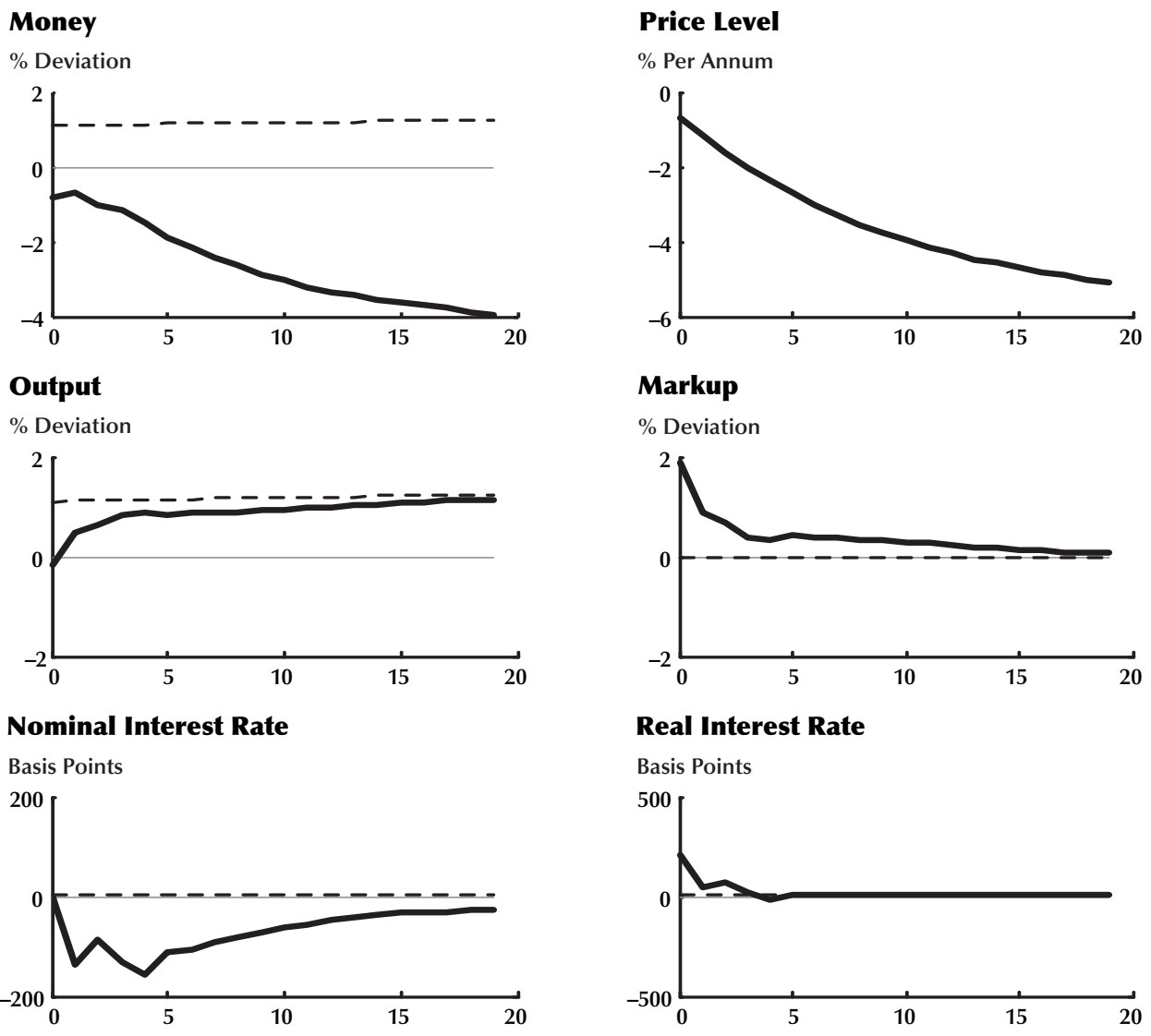

neutrality, there is the comovement of the real rate, the inflation rate, and the nominal interest rate highlighted by the simple model considered in section 4.1. In line with that example, a consequence of the interest rate rule is that the short-run "leaning against" fluctuations in the nominal rate of interest leads to greater medium-term volatility in inflation and the nominal rate, which is related to concerns expressed by Friedman (1968) and Poole (1978).

\subsection{The Standard Taylor Rule}

With a Taylor response to the approximate output gap, $\left(\tau_{2}=0.5\right)$, a very different pattern of response to government purchase and produc- tivity shocks is displayed in Figures 5 and 7. As indicated by the money supply responses in the first panel of each figure, the central bank does not exacerbate economic fluctuations in the short run under such a Taylor-style interest rate rule. Instead, the interest rate rule works to restrain variations in output, relative to the neutral solution. (Again, this neutral solution is the dashed line in each figure.)

\subsubsection{Government Purchases. An increase} in government purchases increases output and the real interest rate under the neutral solution, but requires a supporting increase in the money stock. Because there is a reduction in the quantity of money relative to the neutral solution, there is a decline in aggregate demand and output (again 


\section{Figure 8}

\section{Decomposition of Nominal Interest Rate Variations in Response to a Productivity Shock Under the Taylor Rule}

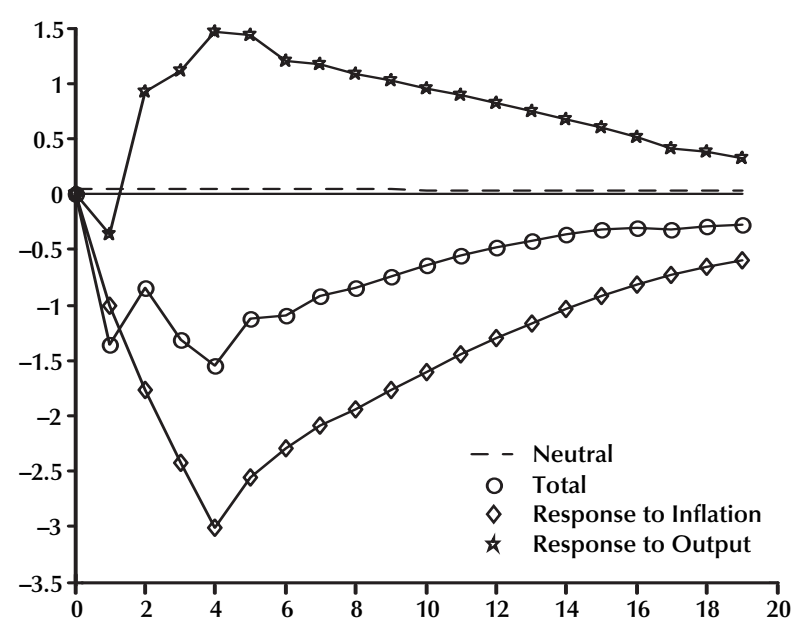

relative to the neutral solution). The decline in demand also induces a subset of firms to adjust prices downward, with a resulting decrease in the price level and an increase in the real markups of the average firm. Because output is temporarily reduced-relative to the neutral benchmarkand because there is a modest expected deflation, the real interest rate rises on impact while the nominal rate is fixed.

There are interesting dynamic elements of the behavior of nominal interest rates under the Taylor rule, displayed in Figure 6. There are two features of importance. First, given the rise in output that takes place due to the increase in government purchases, the Taylor rule coefficient of $\tau_{y}=0.5$ implies that there is an initial rise in the nominal interest rate path. Second, after the initial year or so, high inflation is an inheritance of a shock to government purchases, as in our example noted previously.

4.3.2 Productivity. A permanent increase in productivity raises output permanently and the real interest rate temporarily under the neutral solution, but again requires a supporting increase in the money stock. The Taylor rule dramatically alters the effects of this shock relative to the neutral solution: It leads to a sharp rise in the real interest rate as output adjusts only gradually toward its new higher level. In our context, then, the Taylor rule is consistent with the effects of productivity shocks that Galí (1999) displays in a sticky price model with an exogenous money stock.

By looking at the path of the quantity of money, the short-run parts of the dynamic responses are again relatively easy to understand. When the productivity shock takes place, the quantity of money immediately declines. This leads to a decline in the level of output even though productivity has risen, a decline in the price level, and a sharp rise in the average markup charged by firms. Since output is temporarily low relative to the neutral path (and relative to the long-run level), there is a substantial increase in the real interest rate. The Taylor rule is consistent with these changes because the nominal interest rate is held fixed, while expected deflation occurs.

The dynamic response to inflation and real activity built into the Taylor rule also means that there are longer-lasting effects of the productivity shock on the path of inflation and the nominal interest rate. The productivity shock gives rise to a sustained period of deflation, during which the nominal interest rate is low. Figure 8 shows that the dominant quantitative effect on interest rate policy is from inflation, but that there is also a contribution from output being high relative to the central bank's response to a slowly evolving measure of the output gap.

\subsubsection{Relationship to Monetarist Critique(s).} These responses to government purchase and productivity shocks under the Taylor rule illustrate that interest rate rules can "stabilize" rather than "exacerbate" responses to real shocks.

However, the stabilization is likely undesirable, because there is a presumption in these models that the natural rate solution is approximately optimal (see Goodfriend and King, 1997, and Woodford, 2003).

These two examples also show that government purchase and productivity shocks, which both raise the real interest rate, can exert different effects on inflation. Government purchases first 


\section{Figure 9}

\section{Effects of a Rise in Government Purchases Equal to 1 Percent of GDP Under the Orphanides- Wieland Rule}
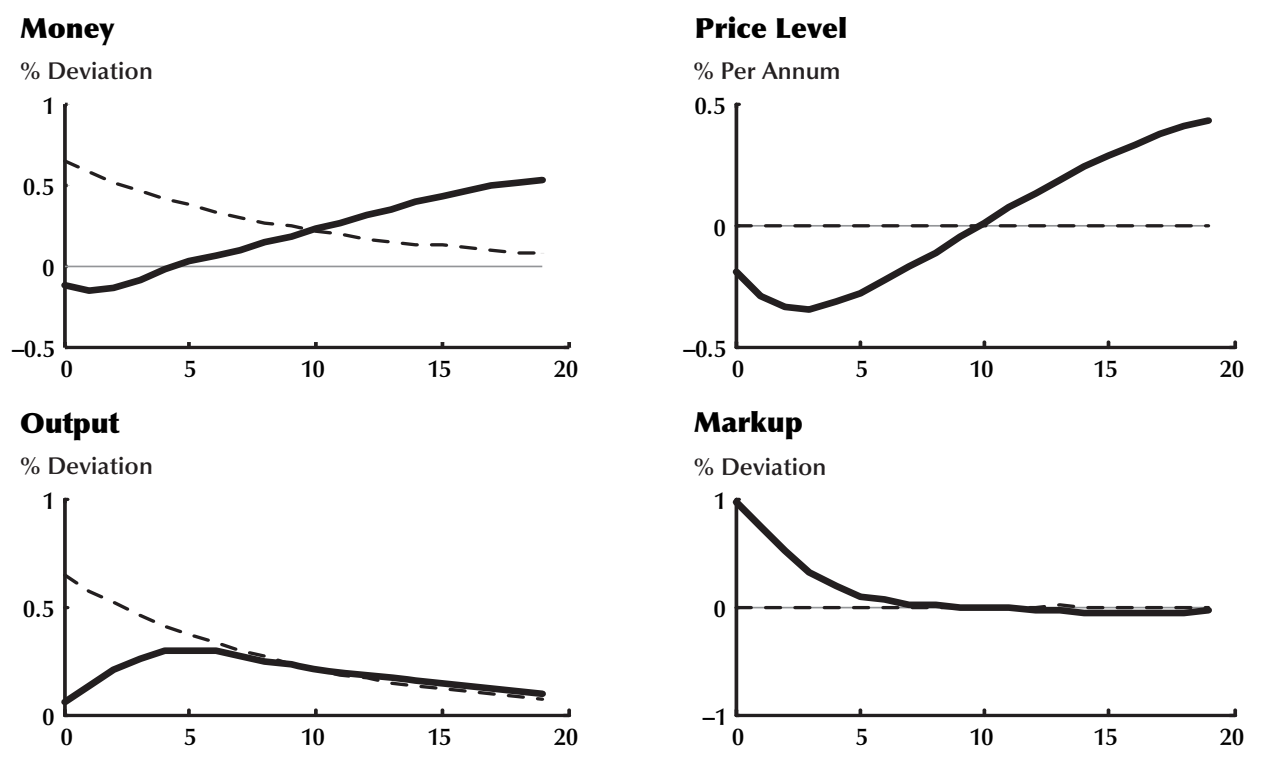

Markup

$\%$ Deviation
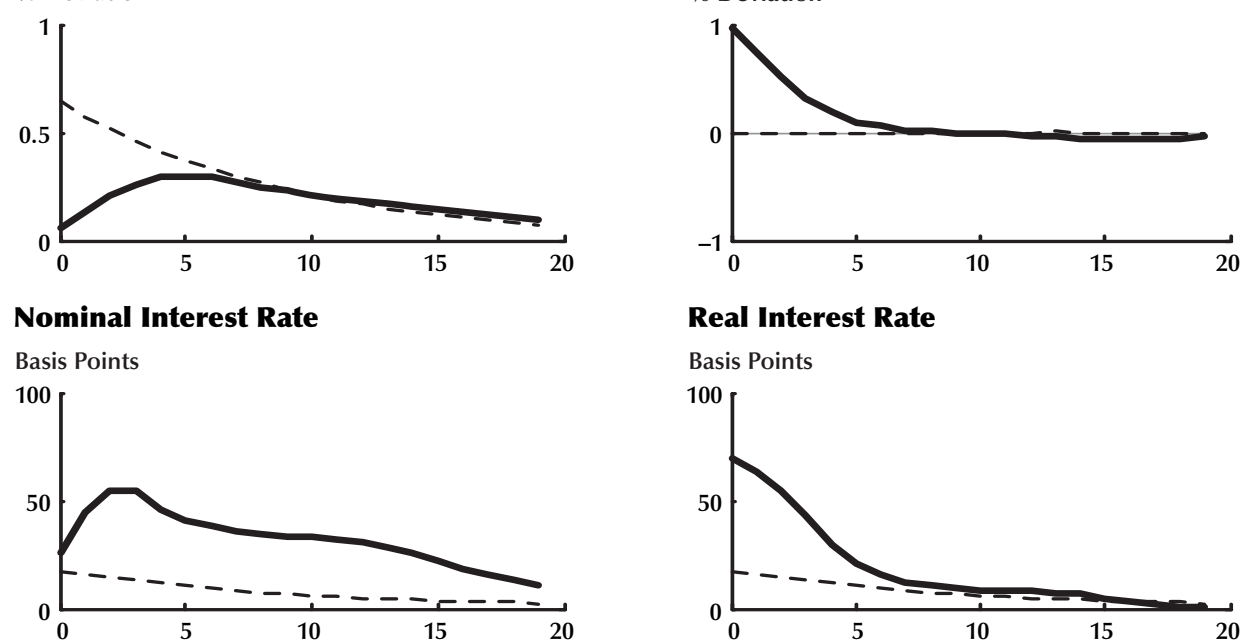

Real Interest Rate

Basis Points

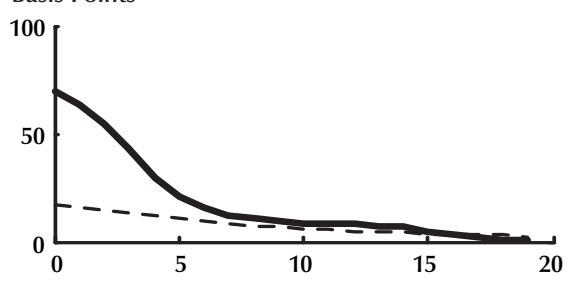

decrease and then increase the inflation rate; productivity movements decrease it under the Taylor rule. Because these variations are largely anticipated after a year or so, they are manifest in high or low nominal interest rates during the latter portions of the dynamic responses.

\subsection{An Estimated Rule}

There has been much recent interest in estimating interest rate rules for the United States and other countries. Typically, these studies turn up support for one or more interest rate lags and one or more output gap lags. The estimated rule of Orphanides and Wieland (1998) is representative in this regard. Figures 9 and 10 provide an indication of the effects of such an estimated rule within our model.

In terms of government purchases, the responses in Figure 9 look much like "a smoother Taylor model," with the main features preserved from that simpler specification. ${ }^{10}$ The OrphanidesWieland rule leads output to respond less to government purchases in the short run than it would under the neutral specification. When there are increases in demand, the OrphanidesWieland rule also leads to a short period of declining prices followed by inflation.

${ }^{10}$ One exception is that the nominal interest rate is not predetermined under the Orphanides-Wieland rule because the central bank responds contemporaneously to output. 
Figure 10

Effects of a 1 Percent Rise in Productivity Under the Orphanides-Wieland Rule

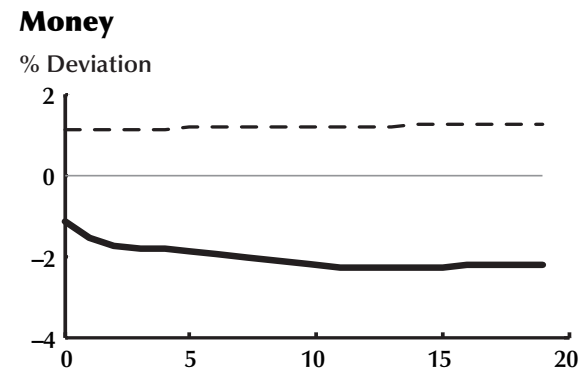

Price Level

$\%$ Per Annum

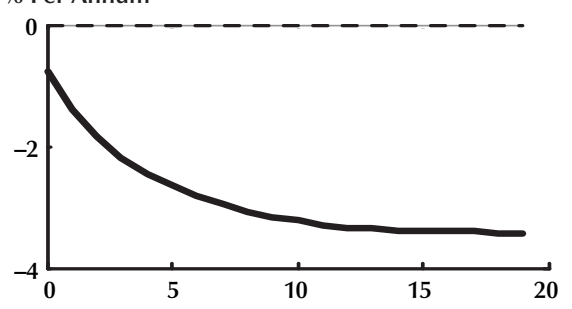

\section{Output}

$\%$ Deviation

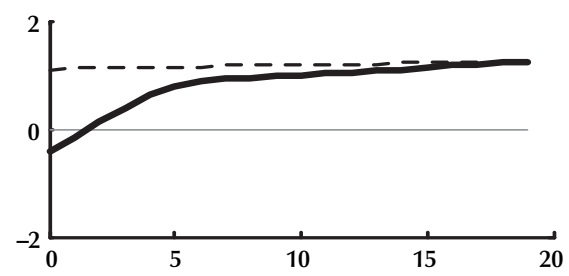

Nominal Interest Rate

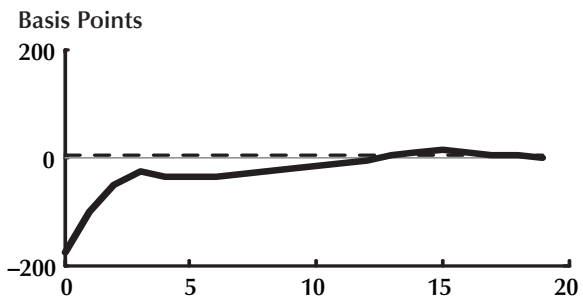

\section{Markup}

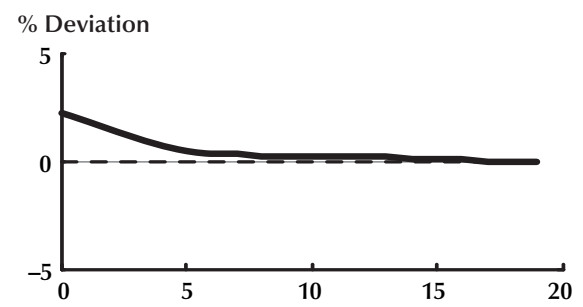

Real Interest Rate

Basis Points

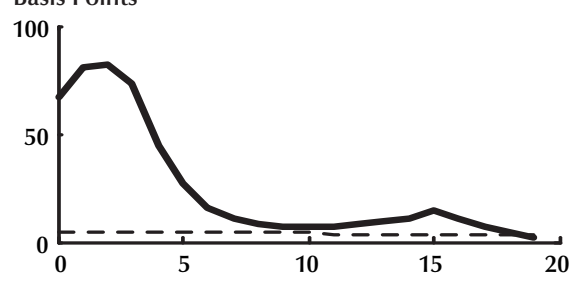

In terms of productivity shocks, the responses in Figure 10 also inherit the main features of the Taylor rule, although yielding a smoother and more-protracted pattern of responses. The Orphanides-Wieland interest rate rule retards the expansion of output from the productivity shock, inducing a rise in the markup and the real interest rate in the early stages of the expansion. A decline in the money stock and the price level accompany the productivity expansion.

\section{CONCLUSIONS}

We view the analysis in this article as our first step in reassessing the continuing relevance of the monetarist critique of interest rate rules to two important topics. First, we are interested in whether these concerns are important for understanding aspects of the macroeconomic history of the United States and other countries. That is, did the use of specific interest rate rules for monetary policy exacerbate or stabilize the business cycle fluctuations that would have arisen from real shocks? Second, we are interested in whether these concerns are important to the design of good operating rules for monetary policy. That is, how large are the departures of specific interest rate rules from optimal policies?

Our analysis highlights the role that real factors can play in both of these investigations. With sticky prices, interest rate rules can produce real outcomes that diverge from the real business cycle responses that would be delivered by neutral 
policy, with the policy rules either exacerbating or stabilizing the real cycle. As suggested by monetarist economists-like Brunner, Friedman, and Poole-variations in the money stock are one set of indicators of these departures. However, our modern model specifies that the relevant monetary indicator is the gap between the money supply response under a specific interest rate rule and that which would occur under a neutral policy that effectively accommodated real shocks. In addition, our modern model suggests that interest rate rules increase the lower-frequency variability of inflation.

\section{REFERENCES}

Baxter, Marianne and King, Robert G. "Fiscal Policy in General Equilibrium." American Economic Review, June 1993, 83(3), pp. 315-34.

Brunner, Karl. "Commentary on Monetary Economics: An Interview with Karl Brunner.” The Banker, July 1978, 128(629), pp. 20-23. Reprinted in Federal Reserve Bank of St. Louis Review, November 1978, 60(11), pp. 2-7.

Calvo, Guillermo A. "Staggered Prices in a UtilityMaximizing Framework." Journal of Monetary Economics, 1983, 12(3), pp. 383-98.

Dixit, Avinash K. and Stiglitz, Joseph E. "Monopolistic Competition and Optimum Product Diversity." American Economic Review, 1977, 67(3), pp. 297308.

Dotsey, Michael. "Structure from Shocks." Federal Reserve Bank of Richmond Economic Quarterly, Fall 2002, 88(4), pp. 1-13.

Friedman, Milton. "The Role of Monetary Policy." American Economic Review, May 1968, 58, pp. 1-17.

Friedman, Milton. "The Optimum Quantity of Money," in The Optimum Quantity of Money and Other Essays. Chicago: Aldine, 1969.

Friedman, Milton. "Monetarism in Rhetoric and Practice,” in Albert Ando, ed., Monetary Policy in
Our Times. Proceedings of the First International Conference held by the Institute for Monetary and Economic Studies of the Bank of Japan. Cambridge, MA: MIT Press, 1985, p. 21.

Galí, Jordi. “Technology, Employment, and the Business Cycle: Do Technology Shocks Explain Aggregate Fluctuations?" American Economic Review, March 1999, 89(1), pp. 249-71.

Goodfriend, Marvin and King, Robert G. "The New Neoclassical Synthesis and the Role of Monetary Policy," in Ben S. Bernanke and Julio J. Rotemberg, eds., NBER Macroeconomics Annual 1997.

Cambridge, MA: MIT Press, 1997, pp. 231-83.

Hayashi, Fumio. "Tobin’s Marginal q and Average q: A Neoclassical Interpretation.” Econometrica, January 1982, 50(1), pp. 213-24.

Kimball, Miles S. "The Quantitative Analytics of the Basic Neomonetarist Model.” Journal of Money, Credit, and Banking, 1995, 27(4 Part 2), pp. 1241-77.

King, Robert G. and Watson, Mark W. "Money, Prices Interest Rates and the Business Cycle." Review of Economics and Statistics, February 1996, 78(1), pp. 35-53.

King, Robert G. and Wolman, Alexander L. "Inflation Targeting in a St. Louis Model of the 21st Century." Federal Reserve Bank of St. Louis Review, May/June 1996, 78(3), pp. 83-107.

Lucas, Robert E. Jr. “Econometric Policy Evaluation: A Critique." Carnegie-Rochester Conference Series on Public Policy, 1976, (1), pp. 19-46.

Orphanides, Athanasios and Wieland, Volker. "Price Stability and Monetary Policy Effectiveness when Nominal Interest Rates Are Bounded at Zero." Finance and Economics Discussion Series, 1998-35. Board of Governors of the Federal Reserve System, 1998; www.federalreserve.gov/pubs/feds/1998/ 199835/199835abs.html.

Poole, William. Money and the Economy: A Monetarist View. Reading, MA: Addison-Wesley, 1978. 


\section{King and Lin}

Rotemberg, Julio J. “The New Keynesian

Microfoundations," in Stanley Fischer, ed., NBER

Macroeconomics Annual 1987. Cambridge, MA:

MIT Press, 1987, pp. 63-129.

Taylor, John B. "Discretion Versus Policy Rules in

Practice.” Carnegie-Rochester Conference Series on Public Policy, 1993, 39, pp. 195-214.

Woodford, Michael. Interest and Prices: Foundations of a Theory of Monetary Policy. Princeton, NJ:

Princeton University Press, 2003.

Yun, Tack. "Nominal Price Rigidity, Money Supply Endogeneity, and Business Cycles.” Journal of Monetary Economics, April 1996, 37, pp. 345-70. 